\title{
Cell adhesion and intracellular calcium signaling in neurons
}

\author{
Lifu Sheng, Iryna Leshchyns'ka and Vladimir Sytnyk
}

\begin{abstract}
Cell adhesion molecules (CAMs) play indispensable roles in the developing and mature brain by regulating neuronal migration and differentiation, neurite outgrowth, axonal fasciculation, synapse formation and synaptic plasticity. CAM-mediated changes in neuronal behavior depend on a number of intracellular signaling cascades including changes in various second messengers, among which CAM-dependent changes in intracellular $\mathrm{Ca}^{2+}$ levels play a prominent role. $\mathrm{Ca}^{2+}$ is an essential secondary intracellular signaling molecule that regulates fundamental cellular functions in various cell types, including neurons. We present a systematic review of the studies reporting changes in intracellular $\mathrm{Ca}^{2+}$ levels in response to activation of the immunoglobulin superfamily CAMs, cadherins and integrins in neurons. We also analyze current experimental evidence on the $\mathrm{Ca}^{2+}$ sources and channels involved in intracellular $\mathrm{Ca}^{2+}$ increases mediated by CAMs of these families, and systematically review the role of the voltage-dependent $\mathrm{Ca}^{2+}$ channels (VDCCs) in neurite outgrowth induced by activation of these CAMs. Molecular mechanisms linking CAMs to VDCCs and intracellular $\mathrm{Ca}^{2+}$ stores in neurons are discussed.
\end{abstract}

Keywords: Cell adhesion molecule, Neurons, Calcium, Voltage dependent $\mathrm{Ca}^{2+}$ channel, Neurite outgrowth

\section{Review}

Cell adhesion molecules (CAMs) expressed on the neuronal cell surface play crucial roles in neuronal migration, axonal fasciculation, and neurite outgrowth during brain development. They also play an important role in regulation of synaptic plasticity in adult brain and axonal regeneration in injured nervous system [1-6].

Functions of CAMs are induced in response to their binding to ligands presented either in the soluble form or on membranes of other cells or on artificial surfaces, a process which is often called CAM activation. CAM activation induces a number of intracellular signaling cascades, which are essential for CAM-mediated functions (for extensive review see [5,7-11]). Among signaling cascades activated by CAMs, changes in intracellular $\mathrm{Ca}^{2+}$ levels have been documented to occur in neurons in response to activation of virtually all families of CAMs, including the three main families comprising the immunoglobulin superfamily (IgSF), cadherins and integrins.

Intracellular $\mathrm{Ca}^{2+}$ serves as a secondary signaling messenger with $\mathrm{Ca}^{2+}$ channels at the neuronal cell surface

\footnotetext{
* Correspondence: v.sytnyk@unsw.edu.au

School of Biotechnology and Biomolecular Sciences, The University of New South Wales, Sydney, New South Wales 2052, Australia
}

and internal $\mathrm{Ca}^{2+}$ stores regulating intracellular $\mathrm{Ca}^{2+}$ concentrations in neurons and other cells. Intracellular $\mathrm{Ca}^{2+}$ has critical roles in all aspects of neuronal development including neurite elongation and neuronal growth cone motility in developing neurons [12-17].

Intracellular signaling cascades activated by CAMs in response to ligand binding induce a number of physiologically important responses in neurons, among which changes in neurite outgrowth are probably the best characterized for CAMs of different families $[5,7,11,18]$. In this review, we systematically analyze studies reporting changes in intracellular $\mathrm{Ca}^{2+}$ levels in response to activation of IgSF CAMs, cadherins and integrins in neurons. We also analyze the experimental evidence supporting the involvement of the cell surface $\mathrm{Ca}^{2+}$ channels and intracellular $\mathrm{Ca}^{2+}$ stores in intracellular $\mathrm{Ca}^{2+}$ changes induced by CAMs of these families, and review the data showing the effects of $\mathrm{Ca}^{2+}$ channel inhibitors on CAM-induced neurite outgrowth.

\section{Changes in intracellular $\mathrm{Ca}^{2+}$ levels induced by activation} of CAMs of the immunoglobulin superfamily (IgSF) CAM-induced increases in intracellular $\mathrm{Ca}^{2+}$ levels were first documented in response to activation of the neural 
cell adhesion molecule (NCAM) and L1, both members of the IgSF (Table 1). NCAM mediates homophilic adhesion, i.e. extracellular domains of NCAM molecules on cell surface membranes of adjacent cells bind to each other. It functions in the developing nervous system by regulating neuronal migration and differentiation and also plays an important role in adult brain by regulating memory formation and brain plasticity $[19,20]$. Application of purified NCAM, which binds to NCAM at the cell surface, induced an increase in intracellular $\mathrm{Ca}^{2+}$ levels in small cerebellar neurons [21]. Similar results were obtained with artificial ligands of NCAM, such as peptide ligands of NCAM, which bind to the extracellular domain of NCAM and which have been shown to induce an increase in intracellular $\mathrm{Ca}^{2+}$ levels in PC12 cells and rat hippocampal neurons loaded with a $\mathrm{Ca}^{2+}$ indicator Fura-2 acetoxymethyl ester (AM) [22,23]. The effects of antibodies against the extracellular domain of NCAM used as an artificial NCAM ligand were analyzed in several studies and have been shown to increase intracellular $\mathrm{Ca}^{2+}$ levels in PC12 cells and in small cerebellar neurons as measured using fluorimetry and a $\mathrm{Ca}^{2+}$ indicator Quin2AM [24,25]. In another study, polyclonal but not monoclonal antibodies against the extracellular domain of NCAM have been shown to induce an increase in intracellular $\mathrm{Ca}^{2+}$ levels in dorsal root ganglion neurons but not in small cerebellar neurons loaded with Fura2AM [21], suggesting that the type of the antibodies used can influence the effects of the antibody on intracellular $\mathrm{Ca}^{2+}$ levels.

CAMs of the L1 family, including L1, close homolog of L1 (CHL1), neurofascin and Neuron-glia cell adhesion molecule (NgCAM), also mediate homophilic adhesion and play a prominent role in the developing central nervous system (CNS) [26,27]. Fluorimetric observations of Quin-2AM loaded cells and microscopical recording of Fura-2AM loaded neurons showed that purified or recombinant L1 and antibodies against the extracellular domain of $\mathrm{L} 1$ induce an increase in intracellular $\mathrm{Ca}^{2+}$ levels in PC12 cells [24], small cerebellar neurons [21,25,28], cortical neurons $[29,30]$, and dorsal root ganglion neurons [21]. $\mathrm{Ca}^{2+}$ influx in response to $\mathrm{L} 1$ activation has also been observed using voltage patch clamp recordings in cortical neurons [30]. In another study, however, activation of L1 had no effect on intracellular $\mathrm{Ca}^{2+}$ levels in Fura-2AM loaded growth cones of dorsal root ganglion neurons [31]. Interestingly, the effect of L1 antibodies depended on the epitope recognized, with one study reporting an increase in intracellular $\mathrm{Ca}^{2+}$ levels in neurons incubated with a monoclonal antibody against an epitope within fibronectin type III repeats of L1, but not in neurons incubated with the monoclonal antibodies against epitopes within immunoglobulin domains [28], suggesting that differences in L1 ligands used may contribute to differences in the effects on intracellular $\mathrm{Ca}^{2+}$ levels. Similar to L1, exposure to immunopurified NgCAM or anti-NgCAM antibodies induced an increase in intracellular $\mathrm{Ca}^{2+}$ levels in neurons from the brains of songbird zebra finch loaded with a $\mathrm{Ca}^{2+}$ indicator Fluo-3AM and analyzed by confocal microscopy [32]. While the role of $\mathrm{Ca}^{2+}$ in signaling induced by another member of this family, CHL1, has been recently suggested [33], the direct evidence that CHL1 can also induce an increase in intracellular $\mathrm{Ca}^{2+}$ levels is still missing.

In addition to NCAM and L1 family members, activation of the immunoglobulin superfamily cell adhesion molecules neuroplastin (Np) and limbic system-associated membrane protein (LAMP) has also been shown to induce increases in intracellular $\mathrm{Ca}^{2+}$ levels. $\mathrm{Np}$ mediates cell-to-cell adhesion via homophilic interactions and is expressed as two isoforms named according to the molecular weight Np55 and Np65. Application of recombinant ectodomains of Np55 and Np65 or a mimicking peptide of Np65 induced an increase in intracellular $\mathrm{Ca}^{2+}$ levels in synapses of cultured hippocampal neurons loaded with a $\mathrm{Ca}^{2+}$ indicator Fluo-4AM [34,35]. Soluble recombinant LAMP has been shown to induce increases in intracellular $\mathrm{Ca}^{2+}$ in hippocampal neurons and neurons from visual cortex loaded with Fluo-3AM [36].

Experiments with inhibitors of various types of $\mathrm{Ca}^{2+}$ channels indicate that changes in intracellular $\mathrm{Ca}^{2+}$ levels in response to activation of IgSF CAMs can be mediated by several classes of VDCCs. Inhibitors of L- and T-type VDCCs reduced the increase in intracellular $\mathrm{Ca}^{2+}$ levels observed in response to NCAM activation in cultured hippocampal neurons [23] and PC12 cells [24]. Pimozide, an inhibitor of T-type VDCCs, was more potent in inhibiting the NCAM-induced $\mathrm{Ca}^{2+}$ response when compared to nifedipine, an inhibitor of L-type VDCCs, in cultured hippocampal neurons [23]. Fluorometric $\mathrm{Ca}^{2+}$ measurements showed that inhibitors of nonselective cation channels also reduced NCAM-dependent $\mathrm{Ca}^{2+}$ influx in Fura-2AM loaded neurons, suggesting that these channels are also activated in response to NCAM ligands [23]. Nifedipine fully blocked and $\omega$-conotoxin, an inhibitor of N-type VDCCs, partially blocked L1-dependent increase in intracellular $\mathrm{Ca}^{2+}[29,30,37]$, while in another study inhibitors of L-type VDCCs verapamil and diltiazem failed to block the L1-dependent $\mathrm{Ca}^{2+}$ influx in mouse dorsal root ganglion neurons and small cerebellar neurons [21]. Nifedipine and $\omega$-conotoxin blocked NgCAM-induced $\mathrm{Ca}^{2+}$ influx [32]. The LAMP-induced intracellular $\mathrm{Ca}^{2+}$ increases in hippocampal neurons were fully inhibited by nifedipine but not $\omega$-conotoxin [36]. Altogether, these data indicate that different members of IgSF act at different VDCCs in a tissue specific manner.

Not only inhibitors of cell surface $\mathrm{Ca}^{2+}$ channels, but also depletion of the internal $\mathrm{Ca}^{2+}$ stores by incubation 
Table 1 An overview of CAMs, activation of which induces an increase in intracellular $\mathrm{Ca}^{2+}$ levels

\begin{tabular}{|c|c|c|c|c|c|c|}
\hline CAMs & Method $/ \mathrm{Ca}^{2+}$ indicator & Ligand, concentration & Cell types (localization) & $\begin{array}{l}\text { Effect on } \\
\mathrm{Ca}^{2+}\end{array}$ & $\begin{array}{l}\text { Inhibitors tested (effect on } \\
\text { ligand induced } \mathrm{Ca}^{2+} \text { increase) }\end{array}$ & References \\
\hline \multicolumn{7}{|l|}{ IgSF } \\
\hline \multirow[t]{24}{*}{ NCAM } & \multirow[t]{3}{*}{ Fluorimetry/Quin-2AM } & \multirow[t]{3}{*}{ Polyclonal NCAM antibodies, $0.4-1 \mathrm{mg} / \mathrm{ml}$} & \multirow[t]{3}{*}{ PC12 cells } & \multirow[t]{3}{*}{$\uparrow$} & Verapamil (full inhibition) & \multirow[t]{3}{*}{ [24] } \\
\hline & & & & & Diltiazem (full inhibition) & \\
\hline & & & & & Nifedipine (no effect) & \\
\hline & Microscopy/Fura-2AM & $\begin{array}{l}\text { Synthetic peptide ligand of NCAM } \\
\text { ectodomain, } 50 \mu \mathrm{M}\end{array}$ & PC12-E2 cells & $\uparrow$ & Not tested & [22] \\
\hline & Fluorimetry/Quin-2AM & $\begin{array}{l}\text { Fab fragments of monoclonal NCAM } \\
\text { antibodies }(\mathrm{H} 28), 0.1-0.2 \mathrm{mg} / \mathrm{ml}\end{array}$ & PC12 cells & No effect & Not tested & [24] \\
\hline & Microscopy/Fura-2AM & Polyclonal NCAM antibodies, $0.3-0.5 \mathrm{mg} / \mathrm{ml}$ & PC12 cells & $\uparrow$ & Not tested & [21] \\
\hline & Microscopy/Fura-2AM & Monoclonal NCAM antibodies, $0.1 \mathrm{mg} / \mathrm{ml}$ & PC12 cells & No effect & Not tested & [21] \\
\hline & Microscopy/Fura-2AM & NCAM antibodies, $0.5 \mathrm{mg} / \mathrm{ml}$ & Chick ciliary ganglion neurons & No effect & Not tested & [39] \\
\hline & Microscopy/Fura-2AM & Polyclonal NCAM antibodies, $0.3-1 \mathrm{mg} / \mathrm{ml}$ & Mouse dorsal root ganglion neurons & $\uparrow$ & Not tested & [21] \\
\hline & Microscopy/Fura-2AM & Monoclonal NCAM antibodies, $0.1 \mathrm{mg} / \mathrm{ml}$ & Mouse dorsal root ganglion neurons & No effect & Not tested & [21] \\
\hline & Microscopy/Fura-2AM & Polyclonal NCAM antibodies, $0.5 \mathrm{mg} / \mathrm{ml}$ & Mouse small cerebellar neurons & No effect & Not tested & [21] \\
\hline & Microscopy/Fura-2AM & Monoclonal NCAM antibodies, $0.1 \mathrm{mg} / \mathrm{ml}$ & Mouse small cerebellar neurons & No effect & Not tested & {$[21]$} \\
\hline & Microscopy/Fura-2AM & Purified NCAM from mouse brain, $10 \mu \mathrm{g} / \mathrm{ml}$ & Mouse small cerebellar neurons & $\uparrow$ & Not tested & {$[21,25]$} \\
\hline & Microscopy/Fura-2AM & $\begin{array}{l}\text { Recombinant fragments of NCAM } \\
\text { ectodomain, } 0.8 \mu \mathrm{M}\end{array}$ & Mouse small cerebellar neurons & $\uparrow$ & Not tested & {$[25]$} \\
\hline & Microscopy/Fura-2AM & Monoclonal NCAM antibodies, 30 mg/ml & Mouse cortical neurons (soma) & No effect & Not tested & {$[29,30]$} \\
\hline & \multirow[t]{2}{*}{ Microscopy/Fura-2AM } & $\begin{array}{l}\text { Synthetic peptide ligand of ectodomain } \\
\text { NCAM, } 54 \mu \mathrm{M}\end{array}$ & Rat hippocampal neurons & $\uparrow$ & Not tested & [22] \\
\hline & & Polyclonal NCAM antibodies, $1 \mathrm{mg} / \mathrm{ml}$ & Rat hippocampal neurons & $\uparrow$ & Not tested & {$[22]$} \\
\hline & \multirow{7}{*}{$\begin{array}{l}\text { Microscopy/ Fura-2AM or } \\
\text { Fluo-4AM }\end{array}$} & \multirow{7}{*}{$\begin{array}{l}\text { Synthetic peptide ligand of NCAM, } \\
12-35 \mu \mathrm{M}\end{array}$} & \multirow[t]{7}{*}{ Rat hippocampal neurons (soma) } & \multirow[t]{7}{*}{$\uparrow$} & Nifedipine (partial inhibition) & \multirow[t]{7}{*}[23]{} \\
\hline & & & & & Mibefradil (partial inhibition) & \\
\hline & & & & & Pimozide (full inhibition) & \\
\hline & & & & & $\omega$-conotoxin (no inhibition) & \\
\hline & & & & & Agatoxin (no inhibition) & \\
\hline & & & & & Loe908 (partial inhibition) & \\
\hline & & & & & SKF-96365 (partial inhibition) & \\
\hline \multirow[t]{4}{*}{ L1 } & Fluorimetry/Quin-2AM & Polyclonal L1 antibodies, $0.4-1$ mg/ml & PC12 cells & $\uparrow$ & Not tested & {$[21,24]$} \\
\hline & \multirow[t]{3}{*}{ Microscopy/Fura-2AM } & \multirow[t]{3}{*}{ Polyclonal L1 antibodies, 0.3-1 mg/ml } & \multirow[t]{3}{*}{ Mouse dorsal root ganglion neurons } & \multirow[t]{3}{*}{$\uparrow$} & Verapamil (no effect) & \multirow[t]{3}{*}[21]{} \\
\hline & & & & & Diltiazem (no effect) & \\
\hline & & & & & $\mathrm{Cd}^{2+} / \mathrm{Ni}^{2+}$ (no effect) & \\
\hline
\end{tabular}


Table 1 An overview of CAMs, activation of which induces an increase in intracellular $\mathrm{Ca}^{2+}$ levels (Continued)

\begin{tabular}{|c|c|c|c|c|c|c|}
\hline & \multirow[t]{2}{*}{ Microscopy/Fura-2AM } & \multirow{2}{*}{$\begin{array}{l}\text { Recombinant ectodomain of } \mathrm{L} 1 \\
(\mathrm{~L} 1-\mathrm{Fc}), 10 \mu \mathrm{g} / \mathrm{ml}\end{array}$} & \multirow{2}{*}{$\begin{array}{l}\text { Rat dorsal root ganglion neurons } \\
\text { (growth cones) }\end{array}$} & \multirow[t]{2}{*}{$\overline{\uparrow^{a}}$} & Nifedipine (full inhibition) ${ }^{a}$ & \multirow[t]{2}{*}{ [37] } \\
\hline & & & & & Conotoxin (partial inhibition) ${ }^{a}$ & \\
\hline & Microscopy/Fura-2 dextran & L1 expressed by 3 T3 cells & $\begin{array}{l}\text { Rat dorsal root ganglion neurons } \\
\text { (growth cones) }\end{array}$ & No effect & Not tested & [31] \\
\hline & \multirow[t]{2}{*}{ Whole cell patch-clamp } & \multirow{2}{*}{$\begin{array}{l}\text { Monoclonal L1 antibodies recognizing } \\
\text { glycosylated L1, } 7.5-30 \mu \mathrm{gg} / \mathrm{ml}\end{array}$} & \multirow[t]{2}{*}{ Mouse dorsal root ganglion neurons } & \multirow[t]{2}{*}{$\uparrow$} & Nifedipine (full inhibition) & \multirow[t]{2}{*}{ [30] } \\
\hline & & & & & $\mathrm{Cd}^{2+}$ (full inhibition) & \\
\hline & \multirow[t]{3}{*}{ Microscopy/Fura-2 AM } & \multirow[t]{3}{*}{ Polyclonal L1 antibodies, $0.3-0.5 \mathrm{mg} / \mathrm{ml}$} & \multirow[t]{3}{*}{ Mouse small cerebellar neurons } & \multirow[t]{3}{*}{$\uparrow$} & Verapamil (no effect) & \multirow[t]{3}{*}{ [21] } \\
\hline & & & & & Diltiazem (no effect) & \\
\hline & & & & & $\mathrm{Cd}^{2+} / \mathrm{Ni}^{2+}$ (No effect) & \\
\hline & $\begin{array}{l}\text { Fluorimetry/Quin-2AM; } \\
\text { Microscopy/Fura2AM }\end{array}$ & $\begin{array}{l}\text { Purified L1 from mouse brain, } \\
10 \mu \mathrm{g} / \mathrm{ml} \text { or } 0.8 \mu \mathrm{M}\end{array}$ & Mouse small cerebellar neurons & $\uparrow$ & Not tested & {$[21,25,28]$} \\
\hline & Fluorimetry/Quin-2AM & $\begin{array}{l}\text { Monoclonal L1 antibodies recognizing FNIII } \\
\text { type repeats, } 100 \mu \mathrm{g} / \mathrm{ml}\end{array}$ & Mouse small cerebellar neurons & $\uparrow$ & Not tested & [28] \\
\hline & Fluorimetry/Quin-2AM & $\begin{array}{l}\text { Monoclonal L1 antibodies recognizing lg- } \\
\text { like domains } \mathrm{I}-\mathrm{Vl}, 100 \mathrm{\mu g} / \mathrm{ml}\end{array}$ & Mouse small cerebellar neurons & No effect & Not tested & {$[21,28]$} \\
\hline & Microscopy/Fura-2AM, & \multirow{2}{*}{$\begin{array}{l}\text { Monoclonal L1 antibodies recognizing } \\
\text { glycosylated } L 1,7.5-30 \mu \mathrm{gg} / \mathrm{ml}\end{array}$} & \multirow[t]{2}{*}{ Mouse cortical neurons (soma) } & \multirow[t]{2}{*}{$\uparrow$} & Nifedipine (full inhibition) & \multirow[t]{2}{*}[29,30]{} \\
\hline & Whole cell patch-clamp & & & & $\mathrm{Cd}^{2+}$ (full inhibition) & \\
\hline \multirow[t]{2}{*}{ Np55 } & \multirow[t]{2}{*}{ Microscopy/Fluo-4AM } & \multirow{2}{*}{$\begin{array}{l}\text { Soluble recombinant ectodomain of } \mathrm{Np} 55 \text {, } \\
15 \mu \mathrm{M}\end{array}$} & Rat hippocampal neurons & \multirow[t]{2}{*}{$\uparrow$} & \multirow[t]{2}{*}{ Not tested } & \multirow[t]{2}{*}{ [35] } \\
\hline & & & (synaptic areas) & & & \\
\hline \multirow[t]{4}{*}{ Np65 } & \multirow[t]{2}{*}{ Micriscopy/Fluo-4AM } & \multirow{2}{*}{$\begin{array}{l}\text { Soluble recombinant ectodomain of } \mathrm{Np} 65 \text {, } \\
15 \mu \mathrm{M}\end{array}$} & Rat hippocampal neurons & \multirow[t]{2}{*}{$\uparrow$} & \multirow[t]{2}{*}{ Not tested } & \multirow[t]{2}{*}{ [34] } \\
\hline & & & (synaptic areas) & & & \\
\hline & \multirow[t]{2}{*}{ Micriscopy/Fluo-4AM } & Syntetic peptide ligand of Np65 enplastin, & Rat hippocampal neurons & $\uparrow$ & Not tested & [34] \\
\hline & & & (synaptic areas) & & & \\
\hline $\mathrm{NgCAM}$ & Microscopy/Fluo-3AM; & Purified chicken NgCAM, $1.2 \mu \mathrm{g} / \mathrm{ml}$ & Neostriatal subependymal zone neurons & $\uparrow$ & Nifedipine (full inhibition) & [32] \\
\hline & & & of & & $\omega$-conotoxin (partial inhibition) & \\
\hline & Microscopy/Fluo-3AM; & Polyclonal NgCAM antibodies, 100 mg/ml & Neostriatal subependymal zone neurons & $\uparrow$ & Nifedipine (full inhibition) & [32] \\
\hline & & & & & $\omega$-conotoxin (partial inhibition) & \\
\hline LAMP & Microscopy/Fluo-3AM & Soluble recombinant LAMP, 30 mg/ml & Rat hippocampal neuron & $\uparrow$ & Nifedipine (full inhibition) & [36] \\
\hline & & & & & w-conotoxin (no inhibition) & \\
\hline & Microscopy/Fluo-3AM & Soluble recombinant LAMP, $30 \mu \mathrm{g} / \mathrm{ml}$ & Visual cortex neurons & $\uparrow$ & Not tested & [36] \\
\hline Thy-1 & Microscopy /Fura-2AM & $\begin{array}{l}\text { Fab fragments of monoclonal Thy- } 1 \text { anti } \\
\text { bodies, } 10 \mu \mathrm{g} / \mathrm{ml}\end{array}$ & PC12 cells (cytosol) & No effect & Not tested & [68] \\
\hline
\end{tabular}

ab fragments of monoclonal Thy-1 anti PC12 cells (cytosol) 
Table 1 An overview of CAMs, activation of which induces an increase in intracellular $\mathrm{Ca}^{2+}$ levels (Continued)

\begin{tabular}{|c|c|c|c|c|c|c|}
\hline \multicolumn{7}{|l|}{ Cadherins } \\
\hline \multirow[t]{5}{*}{$\mathrm{N}$-cadherin } & \multirow[t]{2}{*}{ Microscopy/Fura-2AM } & \multirow{2}{*}{$\begin{array}{l}\text { Soluble fragments of } \mathrm{N} \text {-cadherin purified } \\
\text { from brain or retina, } 10 \mu \mathrm{g} / \mathrm{ml}\end{array}$} & Chick ciliary ganglion neurons & \multirow[t]{2}{*}{$\uparrow$} & \multirow{2}{*}{$\begin{array}{l}\text { Mixture of diltiazem and } \\
\omega \text {-conotoxin (no inhibition) }\end{array}$} & \multirow[t]{2}{*}{ [39] } \\
\hline & & & (soma, growth cones) & & & \\
\hline & Whole cell voltage clamp & $\begin{array}{l}\text { Recombinant ectodomain of } \mathrm{N} \text {-cadherin } \\
\text { (N-cadherin-Fc), } 20 \mu \mathrm{g} / \mathrm{ml}\end{array}$ & Chick ciliary ganglion neurons & $\uparrow$ & Not tested & [41] \\
\hline & Microscopy/Fura-2AM & $\begin{array}{l}\text { Soluble recombinant ectodomain of } \\
\mathrm{N} \text {-cadherin ( } \mathrm{N} \text {-cadherin-Fc), } 50 \mathrm{\mu g} / \mathrm{ml}\end{array}$ & Chick retinal ganglion cells & No effect & Not tested & [40] \\
\hline & Microscopy/FFP-18-AM & $\begin{array}{l}\text { Soluble recombinant ectodomain of } \\
\mathrm{N} \text {-cadherin ( } \mathrm{N} \text {-cadherin- } \mathrm{Fc} \text { ), } 50 \mu \mathrm{g} / \mathrm{ml}\end{array}$ & $\begin{array}{l}\text { Chick retinal ganglion cells (subplasma } \\
\text { membrane of growth cones) }\end{array}$ & $\uparrow$ & $\begin{array}{l}\text { Mixture of nifedipine and } \\
\omega \text {-conotoxin (partial inhibition) }\end{array}$ & [40] \\
\hline $\begin{array}{l}\text { Celsr2/ } \\
\text { Celsr3 }\end{array}$ & Microscopy/Fura-2AM & $\begin{array}{l}\text { Soluble recombinant cadherin repeats } \\
\text { of Celsr } 2 / C e l s r 3,1 \mu \mathrm{g} / \mathrm{ml}\end{array}$ & Rat hippocampal neurons & $\uparrow$ & Not tested & [38] \\
\hline \multicolumn{7}{|l|}{ Integrins } \\
\hline \multirow[t]{9}{*}{$\beta$ Integrin } & $\begin{array}{l}\text { Microscopy/Fura-2AM, } \\
\text { whole cell voltage clamp }\end{array}$ & RGD peptide (cGRGDSPA), $1 \mu \mathrm{M}$ & $\begin{array}{l}\text { L. stagnalis CNS motoneurons } \\
\text { (soma) }\end{array}$ & $\uparrow$ & Not tested & [48] \\
\hline & $\begin{array}{l}\text { High-speed microscopy/ } \\
\text { Fluo-4AM }\end{array}$ & Synthetic RGD peptide (RGDS), 0.5-1 $\mu \mathrm{M}$ & Xenopus spinal neurons (growth cones) & $\uparrow$ & Not tested & [44] \\
\hline & Microscopy/Fura-2AM & Soluble Laminin, $20 \mu \mathrm{g} / \mathrm{ml}$ & Chick ciliary ganglion neurons (soma) & $\uparrow$ & $\begin{array}{l}\text { Mixture of diltiazem and } \\
\omega \text {-conotoxin (no inhibition) }\end{array}$ & [39] \\
\hline & Microscopy/Fura-2AM & $\begin{array}{l}\text { Laminin, immobilized to the beads, } \\
50 \mathrm{\mu g} / \mathrm{ml}\end{array}$ & $\begin{array}{l}\text { Chick dorsal root ganglion neurons } \\
\text { (growth cones) }\end{array}$ & No effect & Not tested & [43] \\
\hline & Microscopy/Fura-2AM & Soluble laminin, $20 \mu \mathrm{g} / \mathrm{ml}$ & $\begin{array}{l}\text { Surgically isolated filopodia from growth cones } \\
\text { of chick dorsal root ganglion neurons }\end{array}$ & $\uparrow$ & Not tested & [43] \\
\hline & \multirow[t]{2}{*}{ Microscopy/Fura-2AM } & \multirow[t]{2}{*}{ RGD peptide (GRGDSP), $10 \mu \mathrm{M}$} & \multirow[t]{2}{*}{ Mouse cortical neurons (soma and neurites) } & \multirow[t]{2}{*}{$\uparrow$} & $\mathrm{Gd}^{3+}$ (partial inhibition) & \multirow[t]{2}{*}{45} \\
\hline & & & & & Nifedipine (partial inhibition) & \\
\hline & Whole cell voltage clamp & $\begin{array}{l}\text { Polyclonal a5 } \beta 1 \text { integrin antibodies, } \\
10 \mu \mathrm{g} / \mathrm{ml}\end{array}$ & Rat basal forebrain neurons & $\uparrow$ & Not tested & [47] \\
\hline & Microscopy/Fura-2AM & Syntetic RGD peptide (GRGDSP), 2.5 mM & Rat cortical neurons & $\uparrow$ & Not tested & [46] \\
\hline
\end{tabular}

aeffect observed in the presence of $\mathrm{Ba}^{2+}$ in the test solution

CAMs, methods used to detect changes in intracellular $\mathrm{Ca}^{2+}$ levels, $\mathrm{Ca}^{2+}$ sensitive indicator used in optical recordings, ligands used to activate $\mathrm{CAMs}$, cell type analyzed and subcellular localization of $\mathrm{Ca}^{2+}$ changes (if

described in the original publication), the effect of CAMs on intracellular $\mathrm{Ca}^{2+}$ levels $\left(\uparrow-\right.$ indicates an increase), the effect of inhibitors of $\mathrm{Ca}^{2+}$ channels on CAM-induced intracellular $\mathrm{Ca}^{2+}$ increases, and respective

references are listed in the table. 
with thapsigargin, a specific inhibitor of the sarcoendoplasmic reticulum $\mathrm{Ca}^{2+}$-ATPase, inhibited an increase in intracellular $\mathrm{Ca}^{2+}$ levels in response to activation of NCAM in cultured hippocampal neurons $[23,38]$ and in response to NgCAM activation in cultured forebrain neurons [32], indicating that $\mathrm{Ca}^{2+}$ influx at the cell surface membrane is accompanied by the release of $\mathrm{Ca}^{2+}$ from the internal stores. Internal $\mathrm{Ca}^{2+}$ stores have also been suggested to contribute to intracellular $\mathrm{Ca}^{2+}$ increases in response to activation of Np55 [35].

\section{Changes in intracellular $\mathrm{Ca}^{2+}$ levels induced by activation of cadherins}

Optical recordings of chick ciliary ganglion neurons loaded with Fura-2AM showed that application of soluble fragments of $\mathrm{N}$-cadherin purified from brain resulted in an increase in intracellular $\mathrm{Ca}^{2+}$ levels in growth cones and cell bodies of neurons [39]. Increased steady state levels of intracellular $\mathrm{Ca}^{2+}$ were also recorded in growth cones of chick retinal ganglion cells grown on $\mathrm{N}$-cadherin and loaded with a membrane targeted $\mathrm{Ca}^{2+}$ indicator, FFP$18 \mathrm{AM}$ [40]. Interestingly, when the Fura-2AM reporter was used, steady state levels of intracellular $\mathrm{Ca}^{2+}$ were found to be not affected by substrate coated recombinant $\mathrm{N}$-cadherin suggesting that $\mathrm{N}$-cadherin influences predominantly submembrane $\mathrm{Ca}^{2+}$ levels [40]. Whole cell voltage clamp recordings also showed that homophilic binding of N-cadherin on neuronal membranes to soluble $\mathrm{N}$-cadherin or N-cadherin overexpressed in Chinese hamster ovary $(\mathrm{CHO})$ cells increases amplitudes of $\mathrm{Ca}^{2+}$ currents in ciliary ganglion neurons indicating that homophilic interactions of $\mathrm{N}$-cadherin are sufficient to activate a cellular mechanism that regulates $\mathrm{Ca}^{2+}$ influx [41].

Similarly to members of IgSF, experiments with inhibitors of various types of $\mathrm{Ca}^{2+}$ channels suggest that VDCCs play an important role in cadherin-induced increases in intracellular $\mathrm{Ca}^{2+}$ levels. In particular, co-application of nifedipine and $\omega$-conotoxin partially reduced the increase in intracellular $\mathrm{Ca}^{2+}$ levels in response to $\mathrm{N}$-cadherin activation in retinal ganglion cells [40], suggesting that $\mathrm{L}$ - and T-type VDCCs are involved in N-cadherin induced $\mathrm{Ca}^{2+}$ influx in neurons. It should be noted, however, that inhibitors of N- and L-type VDCCs $\omega$-conotoxin and diltiazem had no significant effect to $\mathrm{N}$-cadherin-induced $\mathrm{Ca}^{2+}$ response in ciliary ganglion neurons [39].

In addition to $\mathrm{N}$-cadherin, increases in intracellular $\mathrm{Ca}^{2+}$ levels have been shown to occur in response to activation of atypical cadherins Celsr2 and Celsr3, which are highly expressed in hippocampal and cortical neurons [42]. Optical imaging of cultured hippocampal neurons loaded with Fura-2AM showed that intracellular $\mathrm{Ca}^{2+}$ levels increased in response to recombinant cadherin repeats of Celsr3 and Celsr2 with a more pronounced effect observed in response to activation of Celsr2 when compared to Celsr3 [38]. This increase in intracellular $\mathrm{Ca}^{2+}$ levels in response to activation of Celsr2 or Celsr3 was inhibited by thapsigargin, indicating that intracellular $\mathrm{Ca}^{2+}$ stores play also a role in $\mathrm{Ca}^{2+}$ increases mediated by cadherin family members [38].

\section{Changes in intracellular $\mathrm{Ca}^{2+}$ levels induced by activation of integrins}

Modest increases in intracellular $\mathrm{Ca}^{2+}$ levels were reported to occur in response to exposure of neurons to natural ligands of integrins. Optical recordings showed that laminin induced an increase in intracellular $\mathrm{Ca}^{2+}$ levels in growing Fura-2AM loaded chick ciliary ganglion neurons [39], and in the surgically isolated filopodia of growth cones of chick dorsal root ganglion neurons [43]. Much larger increases in intracellular $\mathrm{Ca}^{2+}$ levels were observed in response to integrin ligand Arginine-Glycine-Aspartic acid (RGD)sequence containing peptides. Optical recordings of Fluo-4AM loaded cultured Xenopus spinal neurons showed that incubation with soluble RGD peptides elevated intracellular $\mathrm{Ca}^{2+}$ levels in growth cones and increased filopodial $\mathrm{Ca}^{2+}$ transient frequency [44]. Similar results were obtained with adult cortical neurons, in which fibronectin application has produced moderate increases in intracellular $\mathrm{Ca}^{2+}$ levels while larger responses were observed in neurons treated with RGD-containing peptides $[45,46]$. Increased $\mathrm{Ca}^{2+}$ currents induced by activation of integrins using multivalent antibodies against integrins were also observed using whole cell patch clamp recordings in neurons acutely dissociated from the medial septum/ diagonal band nucleus of the rat [47]. Both, optical recordings of Fura-2AM loaded cell bodies and whole cell voltage clamp recordings showed that RGD peptides increased depolarization induced increases in intracellular $\mathrm{Ca}^{2+}$ levels in motoneurons isolated from the CNS of the pond snail L. stagnalis [48]. It should be noted, however, that high concentrations of RGD peptides used in some of the previous studies [46] have also been shown to induce integrin-independent increases in intracellular $\mathrm{Ca}^{2+}$ levels, such as via activation the N-methyl-D-aspartate (NMDA) receptors in an integrin-independent manner [49]. Therefore, contribution of integrin-independent sources of $\mathrm{Ca}^{2+}$ to overall increases in intracellular $\mathrm{Ca}^{2+}$ levels in studies using RGD peptides cannot be fully excluded.

Integrin $\beta$-dependent increases in intracellular $\mathrm{Ca}^{2+}$ levels were partially blocked by nifedipine and gadolinium III $\left(\mathrm{Gd}^{3+}\right)$, a broad spectrum VDCC inhibitor, in cortical neurons [45]. However, a mixture of diltiazem and $\omega$ conotoxin did not affect the laminin-induced $\mathrm{Ca}^{2+}$ increases in somata of chick ciliary ganglion neurons [39]. Depletion of intracellular $\mathrm{Ca}^{2+}$ stores and inhibitors of the ryanodine receptor (RyR) and inositol 1,4,5-triphosphate gated receptor (IP3R), channels through which $\mathrm{Ca}^{2+}$ in intracellular stores is released into the cytosol, 
also reduced but did not eliminate increases in intracellular $\mathrm{Ca}^{2+}$ levels in response to RGD-containing integrin ligand peptides in cortical neurons [45]. Therefore, $\mathrm{Ca}^{2+}$ influx via VDCCs and $\mathrm{Ca}^{2+}$ release from internal stores can both contribute to the elevation of intracellular $\mathrm{Ca}^{2+}$ levels in response to integrin activation.

\section{Changes in intracellular $\mathrm{Ca}^{2+}$ levels induced by activation of other CAMs}

Changes in intracellular $\mathrm{Ca}^{2+}$ levels have also been reported for other neuronal cell surface molecules involved in neuronal adhesion, notably for amyloid precursor protein (APP) and cellular prion protein (PrP). Optical recordings of B103 rat neuroblastoma cells transfected with APP and loaded with Fluo-4AM showed an increase in intracellular $\mathrm{Ca}^{2+}$ levels in response to incubation with amyloid beta $(\mathrm{A} \beta)$, an APP-derived toxic peptide accumulating in brains of Alzheimer's disease patients. Since no changes in intracellular $\mathrm{Ca}^{2+}$ levels in response to $\mathrm{A} \beta$ occured in cells non-transfected with APP, it was proposed that binding of $\mathrm{A} \beta$ to APP induced $\mathrm{Ca}^{2+}$ influx in these cells [50]. Dysregulation of $\mathrm{Ca}^{2+}$ signaling has been also found in astrocytes from mice missing APP [51].

An increase in intracellular $\mathrm{Ca}^{2+}$ levels have been observed in synaptosomes incubated with recombinant PrP, while function blocking antibodies against PrP inhibited depolarization induced $\mathrm{Ca}^{2+}$ influx via synaptosomal VDCCs, indicating that PrP also plays a role in regulation of intracellular $\mathrm{Ca}^{2+}$ levels [52]. PrP dependent $\mathrm{Ca}^{2+}$-influx has been shown to occur in response to such ligands of PrP as laminin and stress-inducible protein 1 in dorsal root ganglion neurons loaded with Fluo-3AM [53]. Reduced depolarization induced $\mathrm{Ca}^{2+}$ influx has been observed using Fura-2AM and a $\mathrm{Ca}^{2+}$ indicator Calcium Green-5N in cerebellar granule cells and hippocampal CA1 neurons from PrP deficient mice, respectively $[54,55]$. Both submembrane and intracelluar levels of $\mathrm{Ca}^{2+}$ were affected by PrP deficiency [55].

Reduced $\mathrm{Ca}^{2+}$ currents have been also recorded in mice deficient in $\alpha$-neurexin [56], indicating that neurexinneuroligin adhesion complexes are also involved in regulation of intracellular $\mathrm{Ca}^{2+}$ levels in neurons. Whether binding of $\alpha$-neurexins to neuroligins stimulates $\mathrm{Ca}^{2+}$ influx into neurons remains to be investigated.

The effect of VDCC inhibitors on neurite outgrowth induced by activation of IgSF CAMs, cadherins and integrins

VDCCs have been shown to play a multitude of roles in the developing and adult brain being involved in a number of signaling pathways. The role of different types of VDCCs in various brain functions is beyond the scope of this review and we refer the reader to several recent excellent reviews on this subject [57-63]. Below, we summarise current evidence implicating VDCCs in CAMinduced neurite outgrowth.

Analysis of studies investigating effects of various inhibitors of $\mathrm{Ca}^{2+}$ channels on CAM-induced neurite outgrowth is summarized in Table 2. A study by Doherty and colleagues [64], which demonstrated that inhibitors of L-type and N-type VDCCs inhibit NCAM-mediated neurite outgrowth from PC12 cells in an additive manner, was the first to show the fundamental role of VDCCs in neurite outgrowth mediated by CAMs. NCAM-dependent neurite outgrowth has been also shown to be partially inhibited by the inhibitors of N-, L-, and P/Q-type VDCCs in cultured hippocampal neurons [22,65]. Inhibitors of L-type VDCCs also blocked exocytosis in growth cones induced in response to NCAM activation and required for NCAM-dependent neurite outgrowth [66]. Interestingly and surprisingly, another study showed that inhibitors of T-type VDCCs or inhibitors of nonselective cation channels also completely blocked NCAM-dependent neurite outgrowth in cultured hippocampal neurons [23], suggesting that $\mathrm{Ca}^{2+}$ influx via different $\mathrm{Ca}^{2+}$ channels is necessary to raise the overall levels of intracellular $\mathrm{Ca}^{2+}$ above the threshold required for NCAM-dependent neurite outgrowth. Similarly, L1-dependent neurite outgrowth was blocked by inhibitors of L-type (diltiazem, verapamil, or nifedipine) and N-type ( $\omega$-conotoxin) VDCCs in rat cerebellar neurons and PC12 cells $[31,67]$, and partially inhibited by nifedipine, verapamil and diltiazem in mouse small cerebellar neurons [28]. Neurite outgrowth induced by another member of L1 family, CHL1, was fully blocked by application of either an inhibitor of L- or T-type VDCCs [33]. Inhibitors of L- and N-type VDCCs have been also shown to block neurite outgrowth induced by activation of IgSF cell adhesion molecule Thy-1 $[31,67,68]$. In contrast, neurite outgrowth induced in cultured hippocampal neurons grown on $\mathrm{CHO}$ cells overexpressing LAMP was inhibited by blockers of L- but not N-type VDCCs [36]. Altogether, these observations suggest that $\mathrm{Ca}^{2+}$ influx via distinct $\mathrm{Ca}^{2+}$ channels at the cell surface is required to induce a complete set of molecular changes and responses required for IgSF CAM-dependent neurite outgrowth. This scenario is consistent with the observations showing that VDCCs can activate several independent signaling pathways in growth cones of growing neurites [69].

Similarly to IgSF CAMs, N-cadherin-mediated neurite outgrowth from PC12 cells has been shown to be inhibited by inhibitors of L- and N-type VDCCs in an additive manner [64]. However, inhibitors of L- and N-type VDCCs failed to block $\mathrm{N}$-cadherin-dependent neurite outgrowth in ciliary ganglion neurons [39] indicating that other types of $\mathrm{Ca}^{2+}$ channels are involved in cadherin-dependent neurite outgrowth in these cells. Surprisingly, inhibitors of L- and N-type VDCCs diltiazem and $\omega$-conotoxin 
Table 2 An overview of the effects of the inhibitors of $\mathrm{Ca}^{2+}$ channels on CAM-mediated neurite outgrowth

\begin{tabular}{|c|c|c|c|c|}
\hline CAMs & Cell types & Inhibitors (type of $\mathrm{Ca}^{2+}$ channels) & $\begin{array}{l}\text { Impact on CAM-mediated } \\
\text { neurite outgrowth }\end{array}$ & References \\
\hline \multicolumn{5}{|l|}{ IgSF } \\
\hline \multirow[t]{10}{*}{ NCAM } & PC12 cells & Diltiazem (L-type VDCCs), w-conotoxin (N-type VDCCs) & Partial inhibition & {$[64]$} \\
\hline & & $\begin{array}{l}\text { Mixture of diltiazem and } \omega \text {-conotoxin } \\
\text { (L-type and N-type VDCCs) }\end{array}$ & Full inhibition & {$[64]$} \\
\hline & Rat hippocampal neurons & Nifedipine, Diltiazem (L-type VDCC) & Partial inhibition & {$[22,23,65]$} \\
\hline & Rat hippocampal neurons & $\omega$-conotoxin (N-type VDCCs) & Partial inhibition & {$[22,65]$} \\
\hline & Rat hippocampal neurons & Mixture of diltiazem and $\omega$-conotoxin & Full inhibition & {$[65]$} \\
\hline & & (L-type and N-type VDCCs) & & \\
\hline & Rat hippocampal neurons & $\omega$-agatoxin (P/Q-type VDCCs) & Partial inhibition & {$[22]$} \\
\hline & Rat hippocampal neurons & Mibefradil or pimozide (T-type VDCCs) & Full inhibition & {$[23]$} \\
\hline & Rat hippocampal neurons & $\omega$-conotoxin (N-type VDCCs) & No inhibition & [23] \\
\hline & Rat hippocampal neurons & Loe908 or SKF-96365 (NSCCs) & Full inhibition & {$[23]$} \\
\hline \multirow[t]{7}{*}{ L1-CAM } & PC12 cells & $\begin{array}{l}\text { Verapamil, diltiazem, nifedipine or } \omega \text {-conotoxin } \\
\text { (L-type or N-type VDCCs) }\end{array}$ & Partial inhibition & {$[67]$} \\
\hline & PC12 cells & Mixture of L-type and N-type VDCCs inhibitors & Full inhibition & {$[67]$} \\
\hline & Rat dorsal root ganglion neurons & $\begin{array}{l}\text { W-conotoxin or verapamil (N-type or } \\
\text { L-type VDCCs inhibitors) }\end{array}$ & Full inhibition & {$[31]$} \\
\hline & Rat cerebellar neurons & $\begin{array}{l}\text { Verapamil, diltiazem, nifedipine or } \omega \text {-conotoxin } \\
\text { (L-type or N-type VDCCs) }\end{array}$ & Partial inhibition & {$[67]$} \\
\hline & Rat cerebellar neurons & Mixture of L-type and N-type VDCCs inhibitors & Full inhibition & {$[67]$} \\
\hline & Mouse small cerebellar neurons & Verapamil, diltiazem, or nifedipine & Partial inhibition & {$[28]$} \\
\hline & & (L-type VDCCs) & & \\
\hline \multirow[t]{2}{*}{ CHL1 } & Mouse hippocampal neurons & Nifedipine (L-type VDCCs) & Full inhibition & {$[33]$} \\
\hline & Mouse hippocampal neurons & Pimozide (T-type VDCCs) & Full inhibition & [33] \\
\hline Thy-1 & PC12 cells & $\begin{array}{l}\text { Diltiazem, nifedipine, verapamil or } \\
\omega \text {-conotoxin (L-type or N-type VDCCs) }\end{array}$ & Full inhibition & {$[68]$} \\
\hline \multirow[t]{2}{*}{ LAMP } & Rat hippocampal neurons & Nifedipine (L-type VDCCs) & Partial inhibition & {$[36]$} \\
\hline & Rat hippocampal neurons & $\omega$-conotoxin (N-type VDCCs) & No inhibition & {$[36]$} \\
\hline \multirow[t]{3}{*}{$\mathrm{N}$-cadherin } & PC12 cells & $\begin{array}{l}\text { Diltiazem (L-type VDCCs), w-conotoxin } \\
\text { (N-type VDCCs) }\end{array}$ & Partial inhibition & {$[64]$} \\
\hline & PC12 cells & $\begin{array}{l}\text { Mixture of diltiazem and } \omega \text {-conotoxin } \\
\text { (L-type and N-type VDCCs) }\end{array}$ & Partial inhibition & {$[64]$} \\
\hline & Chick ciliary ganglion neurons & $\begin{array}{l}\text { Mixture of diltiazem and } \omega \text {-conotoxin } \\
\text { (L-type and N-type VDCCs) }\end{array}$ & No inhibition & [39] \\
\hline$\beta$ Integrin & Chick ciliary ganglion neurons & $\begin{array}{l}\text { Mixture of diltiazem and } \omega \text {-conotoxin } \\
\text { (L-type and N-type VDCCs) }\end{array}$ & No inhibition & {$[39]$} \\
\hline
\end{tabular}

CAMs and cell type analyzed, inhibitors used and the impact of the inhibitors on the CAM-dependent neurite outgrowth are described.

had no effect on integrin-mediated laminin-induced neurite outgrowth in ciliary ganglion neurons [39]. Therefore, VDCCs required for integrin mediated neurite outgrowth remain to be identified.

\section{Potential mechanisms linking CAMs to $\mathrm{Ca}^{2+}$ channels}

While data accumulated over the last two decades indicate that activation of CAMs induces an increase in intracellular $\mathrm{Ca}^{2+}$ levels in neurons, the mechanisms of this increase remain incompletely understood and probably involve a number of signaling cascades, which link CAMs to the sources of extra- and intracellular $\mathrm{Ca}^{2+}$ by changing the permeability of the respective channels.

A possibility that CAMs change permeability of VDCCs is supported by the studies on IgSF CAM L1 showing that $\mathrm{Ca}^{2+}$ influx via VDCCs in response to $\mathrm{L} 1$ activation occurs without changes in membrane voltage [37] indicating that L1 promotes $\mathrm{Ca}^{2+}$ influx via changing VDCCs properties. Probably the best characterized signaling pathway activated by IgSF CAMs to induce changes in intracellular $\mathrm{Ca}^{2+}$ levels involves the fibroblast growth factor receptor (FGFR) (Figure 1A). FGFR directly interacts with the 
A

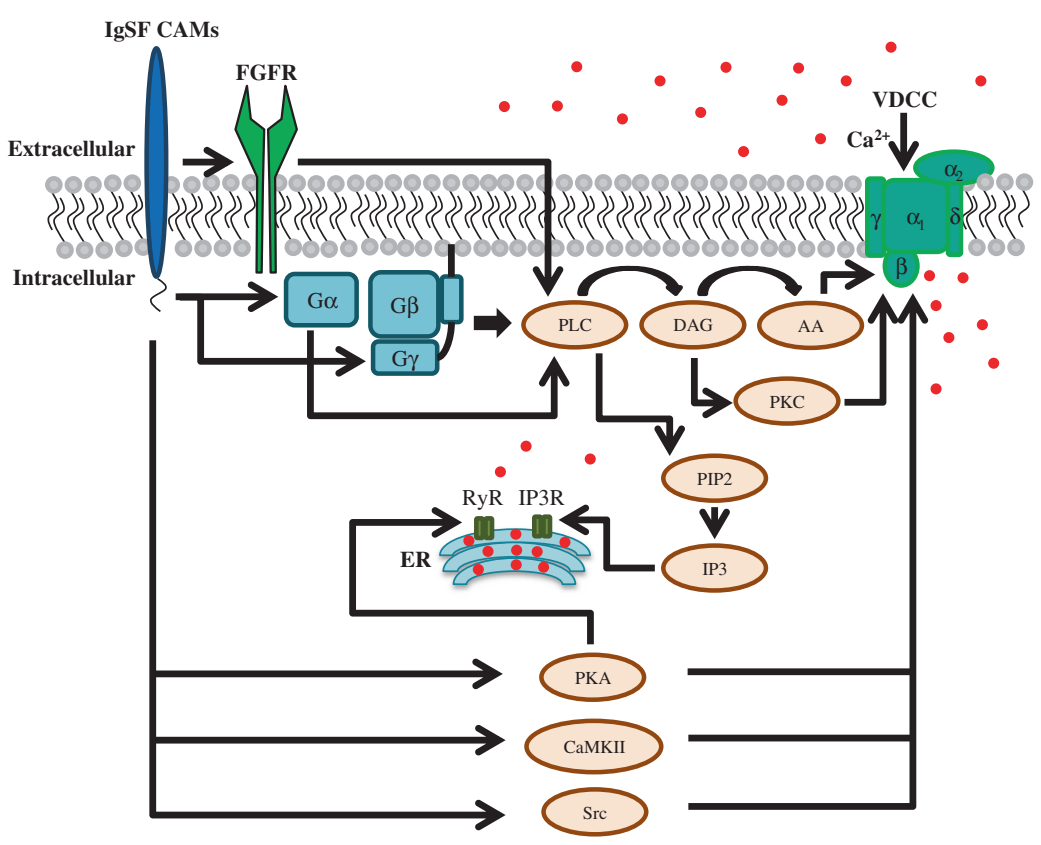

B

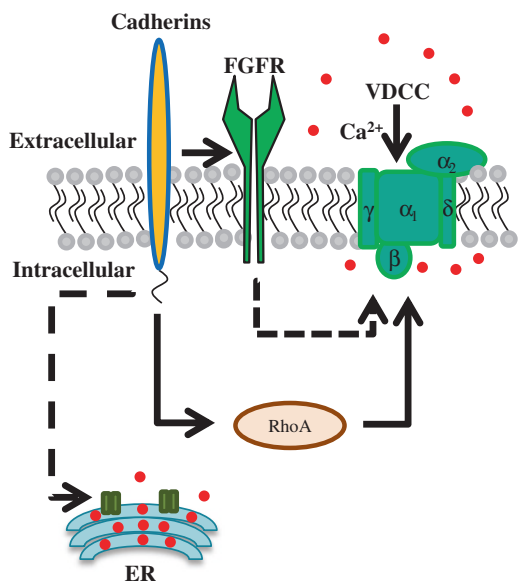

$\mathrm{C}$

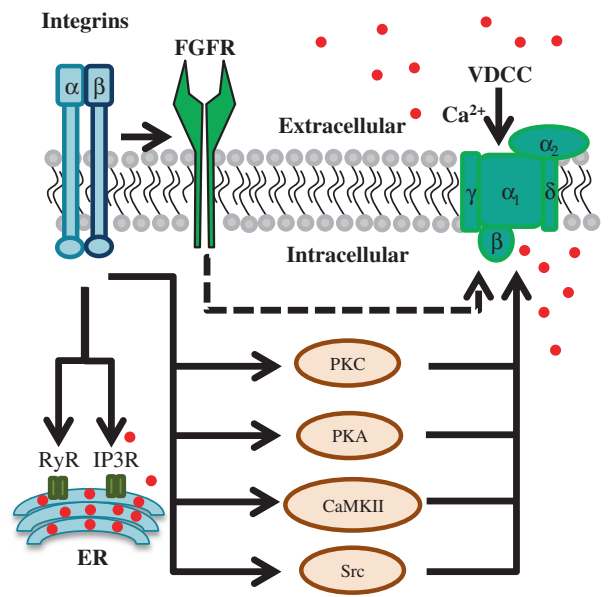

Figure 1 Schematic representation of the possible mechanisms utilized by CAMs to induce an increase in the intracellular $\mathrm{Ca}^{2+}$ levels. IgSF CAMs (A), cadherins (B), and integrins (C) can influence intracellular $\mathrm{Ca}^{2+}$ levels by inducing intracellular signaling cascades converging on VDCCs or inducing $\mathrm{Ca}^{2+}$ release from the internal stores (solid arrows). Known intermediate enzymes involved are also shown. Dashed arrows represent proposed pathways, which have not been experimentally analyzed yet. See text for details and references. FGFR - fibroblast growth factor receptor; VDCC - voltage dependent calcium channels with $a_{1}, a_{2}, \beta, \gamma$, and $\delta$ denoting the subunits of VDCC; $G_{a \prime} G_{\beta}$, and $G_{Y}$ - subunits of the $G$-protein; PLC - phospholipase C; DAG - diacylycerol; AA - arachidonic acid; PKC - protein kinase C; Src - Src-family tyrosine kinase; PKA - protein kinase A; CaMKII - calcium/calmodulin-dependent kinase II; PIP2 - phosphatidylinositol 4, 5-bisphosphate; IP3 - inositol 1,4,5-triphosphate; IP3R - inositol triphosphate receptor; PKA - protein kinase A; RhoA - Ras homolog gene family A; RyR - ryanodine receptor; ER - endoplasmic reticulum.

members of the immunoglobulin superfamily NCAM [70,71], Nectin-1 [72], neuroplastin [35] and L1 [73,74]. It was proposed that activation of FGFR in this pathway is followed by activation of phospholipase C (PLC), which generates diacylglycerol (DAG), which is then converted into arachidonic acid (AA), which then activates VDCCs and subsequently induces $\mathrm{Ca}^{2+}$ influx $[37,75]$. In agreement with this model, ion influx through VDCCs in response to L1 activation was inhibited by a DAG lipase inhibitor and blocked in sensory neurons expressing dominant negative FGFR [37]. Further confirming this model, inhibitors of FGFR and PLC also reduced an increase in intracellular $\mathrm{Ca}^{2+}$ levels in response to NCAM activation in cultured hippocampal neurons [23].

Inhibitors of FGFR do not fully block NCAM-mediated increases in intracellular $\mathrm{Ca}^{2+}$ levels, suggesting that other 
factors also contribute to changes in the levels of intracellular $\mathrm{Ca}^{2+}$. Src-family tyrosine kinases were implicated since inhibitors of this family of tyrosine kinases partially reduced an increase in intracellular $\mathrm{Ca}^{2+}$ levels in response to activation of NCAM in neurons [23]. Src-family tyrosine kinases associate with and regulate the activity of L-type VDCCs [76], and are activated by different members of the immunoglobulin superfamily including NCAM [77] and L1 [78] (Figure 1A). Interestingly, NCAM and $\mathrm{L} 1$ act at different members of the Src-family tyrosine kinase family, fyn and src respectively [78-80]. It remains to be determined whether this influences the ability of NCAM and L1 to activate different VDCCs at the cell surface.

The G protein pathway is another pathway which may contribute to activation of VDCCs [81,82], possibly via inducing PLC activation [83] (Figure 1A). Pertussis toxin (PTX), an inhibitor of the $\mathrm{G}$ protein, inhibited $\mathrm{Ca}^{2+}$ influx in response to activation of NCAM in PC12 cells [24] and in response to $\mathrm{NgCAM}$ in avian forebrain neurons [32].

An increase in intracellular levels of $\mathrm{Ca}^{2+}$ in response to activation of IgSF CAMs at the cell surface has also been linked to activation of a number of $\mathrm{Ca}^{2+}$ dependent enzymes, such as protein kinase $\mathrm{C}$ (PKC) or calcium/calmodulin-dependent kinase II $\alpha$ (CaMKII $\alpha)$, which are activated by NCAM [84-87]. It is therefore possible that PKC and CaMKII provide a positive feedback loop to increase the $\mathrm{Ca}^{2+}$ influx via VDCCs in response to activation of NCAM (Figure 1A). Interestingly, however, the long-term exposure of neurons to the PKC activator phorbol 12-myristate 13-acetate inhibited L1-depenent increases in intracellular $\mathrm{Ca}^{2+}$ levels $[29,88]$, suggesting that PKC may also play a role in reducing intracellular $\mathrm{Ca}^{2+}$ levels following CAM activation.

There is also limited evidence on the interactions between IgSF CAMs and VDCCs in neurons. Both Ltype and T-type VDCCs co-immunoprecipitated with NCAM from the mouse brain lysates indicating that NCAM forms a molecular complex with VDCCs [86]. In response to ligand binding, NCAM redistributes to lipid rafts $[77,89]$, where VDCCs are also accumulated [86]. Whether the interactions between NCAM and VDCCs influence the permeability of VDCCs remains to be investigated.

IgSF CAM-activated signaling pathways can also play a central role in inducing $\mathrm{Ca}^{2+}$ release from internal stores. Inhibitors of PLC inhibited increases in the levels of intracellular $\mathrm{Ca}^{2+}$ in response to NCAM activation, suggesting that $\mathrm{Ca}^{2+}$ release from internal stores occurs in response to inositol-3-phosphate produced by PLC (Figure 1A). Additionally, activation of RyR via cAMP and PKA pathways may also result in $\mathrm{Ca}^{2+}$ release from internal stores [90] (Figure 1A). This CAM-dependent activation of RyR via cAMP and PKA pathways have been shown to have important consequences for neuronal behavior, such as turning of growth cones of growing neurites either towards the source of $\mathrm{Ca}^{2+}$ signal, which occurs on the L1- or N-cadherin substarte, or away from the source of $\mathrm{Ca}^{2+}$ signal which occurs on the laminin substrate in dorsal root ganglion neurons [90].

Similarly to IgSF members cadherins also interact with FGFR [91-93] (Figure 1B). This observation suggests that cadherins can activate signaling pathways which are similar to or partially overlap with signaling pathways activated by IgSF members to induce $\mathrm{Ca}^{2+}$ influx at the cell surface. N-cadherin dependent regulation of VDCCs involves, however, also a small GTPase RhoA [94,95] (Figure 1B).

FGFR also binds to integrins [96], and may be involved in integrin-dependent $\mathrm{Ca}^{2+}$ signalling (Figure 1C). Inhibition of Src family tyrosine kinases also partially reduced an increase in intracellular $\mathrm{Ca}^{2+}$ levels in response to activation integrins in neurons [47], suggesting that kinases of this family are involved (Figure 1C). Integrin-dependent activation of L-type VDCCs has also been shown to be dependent on PKA [47], which phosphorylates VDCCs and facilitates their function [97] (Figure 1C). Laminininduced integrin-mediated increases in intracellular $\mathrm{Ca}^{2+}$ levels in growth cones were also blocked by inhibitors of PKC and CaMKII [43] (Figure 1C).

Integrins have also been found in a complex with VDCCs. Integrins containing $\alpha 3$ subunit are linked to VDCCs by laminin in the Torpedo electric organ synapses [98]. In cerebellar granular neurons, integrin $\alpha 5 \beta 1$ associates with short transient receptor potential channel 5 (TrpC5) [99]. TrpC channels are metabolically-activated $\mathrm{Ca}^{2+}$ channels, which are widely expressed in different tissues and cell types playing diverse physiological functions [100]. They also play a critical role in neuronal development (for extensive review see [101]) and neurite outgrowth in particular $[99,102]$. In non-neuronal human embryonic kidney HEK293 cells, $\alpha 5 \beta 1$-integrin has been shown to associate with L-type VDCCs [103], and liganddependent complex formation between $\beta 1$-integrin and L-type VDCCs has been described in mouse embryonic stem cells [104]. Whether binding of integrins to VDCCs and TRPCs influences permeability of these channels remains however unknown.

\section{Conclusion}

In conclusion, a number of studies indicate that CAMs play an important role in regulation of intracellular $\mathrm{Ca}^{2+}$ levels in neurons by acting at VDCCs and possibly other types of $\mathrm{Ca}^{2+}$ channels in the neuronal cell surface plasma membrane and in the intracellular $\mathrm{Ca}^{2+}$ stores. Not only VDCCs, but also other neuronal plasma membrane $\mathrm{Ca}^{2+}$ channels such as transient receptor potential channels, stretch-activated channels, and cyclic nucleotide-gated 
channels have been reported to play a role in neuronal development [105-107]. Direct links between CAMs and other types of $\mathrm{Ca}^{2+}$ channels in neurons remain however unknown. Current data indicate that CAMs activate $\mathrm{Ca}^{2+}$ channels by inducing intracellular signaling cascades which can either activate or remove inhibition of $\mathrm{Ca}^{2+}$ channels to induce an increase in intracellular $\mathrm{Ca}^{2+}$ levels. It remains to be investigated whether formation of the molecular complexes between CAMs and $\mathrm{Ca}^{2+}$ channels directly influences the activity of the latter.

Most of the previous work was performed using artificial stimulation protocols by applying soluble ligands in the culture medium and monitoring bulk changes in intracellular $\mathrm{Ca}^{2+}$ levels. Better imaging technologies which appeared recently may help to investigate the dynamics of local CAM-dependent $\mathrm{Ca}^{2+}$ changes occurring during cell-to-cell contact formation, and particularly during synapse formation. A combination of such technologies with biochemical analysis and optical imaging of the synapse enriched cytoskeleton components and enzymes may provide valuable information about the mechanisms of the molecular rearrangements accompanying contact maturation. The development of genetically encoded $\mathrm{Ca}^{2+}$ reporters [108-111] with a better defined subcellular localization as compared to chemical dyes used in previous studies may also allow monitoring intracellular $\mathrm{Ca}^{2+}$ levels in CAM-enriched membrane microdomains in different neuronal compartments, which is a promising new direction for further research.

\footnotetext{
Abbreviations

AA: Arachidonic acid; Aß: Amyloid beta; AM: Acetoxymethyl ester; APP: Amyloid precursor protein; CAMs: Cell adhesion molecules; CaMKlla: Calcium/ calmodulin-dependent kinase II $a_{;}$CHL1: Close homolog of L1; CHO: Chinese hamster ovary cells; CNS: Central nervous system; DAG: Diacylglycerol; ER: Endoplasmic reticulum; FGFR: Fibroblast growth factor receptor; HEK 293 cells: Human embryonic kidney 293 cells; IP3: Inositol 1,4,5-triphosphate; IP3R: Inositol 1,4,5-triphosphate gated receptor; LAMP: Limbic system-associated membrane protein; NCAM: Neural cell adhesion molecule; NgCAM: Neuron-glia cell adhesion molecule; NMDA: N-methyl-D-aspartate; Np: Neuroplastin; NSCCs: Nonselective cation channels; PLC: Phospholipase C; PKA: Protein kinase A; PKC: Protein kinase C; PTX: Pertussis toxin; PrP: Prion protein; RGD: Arginine-Glycine-Aspartic acid; RyR: Ryanodine receptor; TrpC5: Transient receptor potential channel 5; VDCCs: Voltage-dependent calcium channels.
}

\section{Competing interests}

The authors declare that they have no competing interests.

\section{Authors' contributions}

$L S$, IL and VS have performed literature search and analysis and written the manuscript. All authors read and approved the final manuscript.

\section{Acknowledgements}

This work was supported by the National Health and Medical Research Council (to VS).

Received: 22 October 2013 Accepted: 5 December 2013

Published: 13 December 2013

\section{References}

1. Tessier-Lavigne M, Goodman CS: The molecular biology of axon guidance. Science 1996, 274:1123-1133.
2. Walsh FS, Meiri K, Doherty P: Cell signalling and CAM-mediated neurite outgrowth. Soc Gen Physiol Ser 1997, 52:221-226.

3. Blackmore M, Letourneau PC: L1, beta1 integrin, and cadherins mediate axonal regeneration in the embryonic spinal cord. J Neurobiol 2006, 66:1564-1583.

4. Nacher J, Guirado R, Castillo-Gomez E: Structural plasticity of interneurons in the adult brain: role of PSA-NCAM and implications for psychiatric disorders. Neurochem Res 2013, 38:1122-1133.

5. Hansen SM, Berezin V, Bock E: Signaling mechanisms of neurite outgrowth induced by the cell adhesion molecules NCAM and N-cadherin. Cell Mol Life Sci 2008, 65:3809-3821.

6. Rutishauser U: Polysialic acid in the plasticity of the developing and adult vertebrate nervous system. Nat Rev Neurosci 2008, 9:26-35.

7. Cavallaro U, Dejana E: Adhesion molecule signalling: not always a sticky business. Nat Rev Mol Cell Biol 2011, 12:189-197.

8. Gahmberg CG, Fagerholm SC, Nurmi SM, Chavakis T, Marchesan S, Gronholm M: Regulation of integrin activity and signalling. Biochim Biophys Acta 2009, 1790:431-444.

9. Aricescu AR, Jones EY: Immunoglobulin superfamily cell adhesion molecules: zippers and signals. Curr Opin Cell Biol 2007, 19:543-550

10. Dalva MB, McClelland AC, Kayser MS: Cell adhesion molecules: signalling functions at the synapse. Nat Rev Neurosci 2007, 8:206-220.

11. Doherty P, Williams G, Williams EJ: CAMs and axonal growth: a critical evaluation of the role of calcium and the MAPK cascade. Mol Cell Neurosci 2000, 16:283-295.

12. Bedlack RS Jr, Wei M, Loew LM: Localized membrane depolarizations and localized calcium influx during electric field-guided neurite growth. Neuron 1992, 9:393-403.

13. Rehder V, Kater SB: Regulation of neuronal growth cone filopodia by intracellular calcium. J Neurosci 1992, 12:3175-3186.

14. Henley JR, Huang KH, Wang D, Poo MM: Calcium mediates bidirectional growth cone turning induced by myelin-associated glycoprotein. Neuron 2004, 44:909-916.

15. Zheng JQ, Poo MM: Calcium signaling in neuronal motility. Annu Rev Cell Dev Biol 2007, 23:375-404.

16. Henley J, Poo MM: Guiding neuronal growth cones using Ca2+ signals. Trends Cell Biol 2004, 14:320-330.

17. Gomez TM, Zheng JQ: The molecular basis for calcium-dependent axon pathfinding. Nat Rev Neurosci 2006, 7:115-125.

18. Maness PF, Schachner M: Neural recognition molecules of the immunoglobulin superfamily: signaling transducers of axon guidance and neuronal migration. Nat Neurosci 2007, 10:19-26.

19. Ditlevsen DK, Povlsen GK, Berezin V, Bock E: NCAM-induced intracellular signaling revisited. J Neurosci Res 2008, 86:727-743.

20. Kraev I, Henneberger C, Rossetti C, Conboy L, Kohler LB, Fantin M, Jennings A, Venero C, Popov V, Rusakov D, et al: A peptide mimetic targeting trans-homophilic NCAM binding sites promotes spatial learning and neural plasticity in the hippocampus. PloS One 2011, 6:e23433.

21. Von Bohlen Und Halbach F, Taylor J, Schachner M: Cell Type-specific Effects of the Neural Adhesion Molecules L1 and N-CAM on Diverse Second Messenger Systems. Eur J Neurosci 1992, 4:896-909.

22. Ronn LC, Dissing S, Holm A, Berezin V, Bock E: Increased intracellular calcium is required for neurite outgrowth induced by a synthetic peptide ligand of NCAM. FEBS Lett 2002, 518:60-66.

23. Kiryushko D, Korshunova I, Berezin V, Bock E: Neural cell adhesion molecule induces intracellular signaling via multiple mechanisms of $\mathrm{Ca} 2$ + homeostasis. Mol Biol Cell 2006, 17:2278-2286.

24. Schuch U, Lohse MJ, Schachner M: Neural cell adhesion molecules influence second messenger systems. Neuron 1989, 3:13-20.

25. Frei T, von Bohlen und Halbach F, Wille W, Schachner M: Different extracellular domains of the neural cell adhesion molecule (N-CAM) are involved in different functions. J Cell Biol 1992, 118:177-194.

26. Brummendorf T, Rathjen FG: Structure/function relationships of axonassociated adhesion receptors of the immunoglobulin superfamily. Curr Opin Neurobiol 1996, 6:584-593.

27. Grumet M: Cell adhesion molecules and their subgroups in the nervous system. Curr Opin Neurobiol 1991, 1:370-376.

28. Appel F, Holm J, Conscience JF, von Bohlen und Halbach F, Faissner A, James P, Schachner M: Identification of the border between fibronectin type III homologous repeats 2 and 3 of the neural cell adhesion 
molecule L1 as a neurite outgrowth promoting and signal transducing domain. J Neurobiol 1995, 28:297-312.

29. Itoh K, Kawamura H, Asou H: A novel monoclonal antibody against carbohydrates of $\mathrm{L} 1$ cell adhesion molecule causes an influx of calcium in cultured cortical neurons. Brain Res 1992, 580:233-240.

30. Asou $\mathrm{H}$ : Monoclonal antibody that recognizes the carbohydrate portion of cell adhesion molecule L1 influences calcium current in cultured neurons. J Cell Physiol 1992, 153:313-320.

31. Harper SJ, Bolsover SR, Walsh FS, Doherty P: Neurite outgrowth stimulated by $L 1$ requires calcium influx into neurons but is not associated with changes in steady state levels of calcium in growth cones. Cell Adhes Commun 1994, 2:441-453.

32. Goldman SA, Williams S, Barami K, Lemmon V, Nedergaard M: Transient coupling of $\mathrm{Ng}$-CAM expression to $\mathrm{NgCAM}$-dependent calcium signaling during migration of new neurons in the adult songbird brain. $\mathrm{Mol} \mathrm{Cell}$ Neurosci 1996, 7:29-45

33. Tian N, Leshchyns'ka I, Welch JH, Diakowski W, Yang H, Schachner M, Sytnyk V: Lipid raft-dependent endocytosis of close homolog of adhesion molecule L1 (CHL1) promotes neuritogenesis. J Biol Chem 2012, 287:44447-44463.

34. Owczarek S, Soroka V, Kiryushko D, Larsen MH, Yuan Q, Sandi C, Berezin V, Bock E: Neuroplastin-65 and a mimetic peptide derived from its homophilic binding site modulate neuritogenesis and neuronal plasticity. J Neurochem 2011, 117:984-994.

35. Owczarek S, Kiryushko D, Larsen MH, Kastrup JS, Gajhede M, Sandi C Berezin V, Bock E, Soroka V: Neuroplastin-55 binds to and signals through the fibroblast growth factor receptor. FASEB J 2010, 24:1139-1150.

36. Zhukareva V, Chernevskaya N, Pimenta A, Nowycky M, Levitt P: Limbic system-associated membrane protein (LAMP) induces neurite outgrowth and intracellular $\mathrm{Ca} 2+$ increase in primary fetal neurons. Mol Cell Neurosci 1997, 10:43-55.

37. Archer FR, Doherty P, Collins D, Bolsover SR: CAMs and FGF cause a local submembrane calcium signal promoting axon outgrowth without a rise in bulk calcium concentration. Eur J Neurosci 1999, 11:3565-3573.

38. Shima Y, Kawaguchi SY, Kosaka K, Nakayama M, Hoshino M, Nabeshima Y, Hirano T, Uemura T: Opposing roles in neurite growth control by two seven-pass transmembrane cadherins. Nat Neurosci 2007, 10:963-969.

39. Bixby JL, Grunwald GB, Bookman RJ: Ca2+ influx and neurite growth in response to purified N-cadherin and laminin. J Cell Biol 1994, 127:1461-1475.

40. Chadborn N, Eickholt B, Doherty P, Bolsover S: Direct measurement of local raised subplasmalemmal calcium concentrations in growth cones advancing on an N-cadherin substrate. Eur J Neurosci 2002, 15:1891-1898.

41. Marrs GS, Theisen CS, Bruses JL: N-cadherin modulates voltage activated calcium influx via RhoA, p120-catenin, and myosin-actin interaction Mol Cell Neurosci 2009, 40:390-400.

42. Shima Y, Copeland NG, Gilbert DJ, Jenkins NA, Chisaka O, Takeichi M, Uemura T: Differential expression of the seven-pass transmembrane cadherin genes Celsr1-3 and distribution of the Celsr2 protein during mouse development. Dev Dyn 2002, 223:321-332.

43. Kuhn TB, Williams CV, Dou P, Kater SB: Laminin directs growth cone navigation via two temporally and functionally distinct calcium signals. J Neurosci 1998, 18:184-194.

44. Gomez TM, Robles E, Poo M, Spitzer NC: Filopodial calcium transients promote substrate-dependent growth cone turning. Science 2001 291:1983-1987.

45. Lin CY, Hilgenberg LG, Smith MA, Lynch G, Gall CM: Integrin regulation of cytoplasmic calcium in excitatory neurons depends upon glutamate receptors and release from intracellular stores. Mol Cell Neurosci 2008, 37:770-780.

46. Watson PM, Humphries MJ, Relton J, Rothwell NJ, Verkhratsky A, Gibson RM: Integrin-binding RGD peptides induce rapid intracellular calcium increases and MAPK signaling in cortical neurons. Mol Cell Neurosci 2007 34:147-154.

47. Gui P, Wu X, Ling S, Stotz SC, Winkfein RJ, Wilson E, Davis GE, Braun AP, Zamponi GW, Davis MJ: Integrin receptor activation triggers converging regulation of Cav1.2 calcium channels by c-Src and protein kinase $A$ pathways. J Biol Chem 2006, 281:14015-14025.

48. Wildering WC, Hermann PM, Bulloch AG: Rapid neuromodulatory actions of integrin ligands. J Neurosci 2002, 22:2419-2426.

49. Cingolani LA, Thalhammer A, Yu LM, Catalano M, Ramos T, Colicos MA, Goda Y: Activity-dependent regulation of synaptic AMPA receptor composition and abundance by beta3 integrins. Neuron 2008, 58:749-762.
50. Shaked GM, Chauv S, Ubhi K, Hansen LA, Masliah E: Interactions between the amyloid precursor protein C-terminal domain and $\mathrm{G}$ proteins mediate calcium dysregulation and amyloid beta toxicity in Alzheimer's disease. FEBS J 2009, 276:2736-2751

51. Linde Cl, Baryshnikov SG, Mazzocco-Spezzia A, Golovina VA: Dysregulation of $\mathrm{Ca} 2+$ signaling in astrocytes from mice lacking amyloid precursor protein. Am J Physiol Cell Physiol 2011, 300:C1502-C1512.

52. Whatley SA, Powell JF, Politopoulou G, Campbell IC, Brammer MJ, Percy NS: Regulation of intracellular free calcium levels by the cellular prion protein. Neuroreport 1995, 6:2333-2337.

53. Santos TG, Beraldo FH, Hajj GN, Lopes MH, Roffe M, Lupinacci FC, Ostapchenko VG, Prado VF, Prado MA, Martins VR: Laminin-gamma1 chain and stress inducible protein 1 synergistically mediate PrPC-dependent axonal growth via Ca2+ mobilization in dorsal root ganglia neurons. J Neurochem 2013, 124:210-223.

54. Herms JW, Korte S, Gall S, Schneider I, Dunker S, Kretzschmar HA: Altered intracellular calcium homeostasis in cerebellar granule cells of prion protein-deficient mice. J Neurochem 2000, 75:1487-1492

55. Fuhrmann M, Bittner T, Mitteregger G, Haider N, Moosmang S, Kretzschmar H, Herms J: Loss of the cellular prion protein affects the Ca2+ homeostasis in hippocampal CA1 neurons. J Neurochem 2006, 98:1876-1885.

56. Missler M, Zhang W, Rohlmann A, Kattenstroth G, Hammer RE, Gottmann K, Sudhof TC: Alpha-neurexins couple $\mathrm{Ca} 2+$ channels to synaptic vesicle exocytosis. Nature 2003, 423:939-948

57. Dolphin AC: Calcium channel diversity: multiple roles of calcium channel subunits. Curr Opin Neurobiol 2009, 19:237-244.

58. Rajakulendran S, Kaski D, Hanna MG: Neuronal P/Q-type calcium channel dysfunction in inherited disorders of the CNS. Nat Rev Neurol 2012, 8:86-96.

59. Calin-Jageman I, Lee A: Ca(v)1 L-type Ca2+ channel signaling complexes in neurons. J Neurochem 2008, 105:573-583.

60. Evans RM, Zamponi GW: Presynaptic Ca2+ channels-integration centers for neuronal signaling pathways. Trends Neurosci 2006, 29:617-624.

61. Neher E, Sakaba T: Multiple roles of calcium ions in the regulation of neurotransmitter release. Neuron 2008, 59:861-872.

62. Cataldi M: The changing landscape of voltage-gated calcium channels in neurovascular disorders and in neurodegenerative diseases. Curr Neuropharmacol 2013, 11:276-297.

63. Lipscombe D, Helton TD, Xu W: L-type calcium channels: the low down. J Neurophysiol 2004, 92:2633-2641.

64. Doherty P, Ashton SV, Moore SE, Walsh FS: Morphoregulatory activities of NCAM and N-cadherin can be accounted for by G protein-dependent activation of L- and N-type neuronal Ca2+ channels. Cell 1991, 67:21-33.

65. Doherty P, Skaper SD, Moore SE, Leon A, Walsh FS: A developmentally regulated switch in neuronal responsiveness to NCAM and N-cadherin in the rat hippocampus. Development 1992, 115:885-892.

66. Chernyshova Y, Leshchyns'ka I, Hsu SC, Schachner M, Sytnyk V: The neural cell adhesion molecule promotes FGFR-dependent phosphorylation and membrane targeting of the exocyst complex to induce exocytosis in growth cones. J Neurosci 2011, 31:3522-3535.

67. Williams EJ, Doherty P, Turner G, Reid RA, Hemperly JJ, Walsh FS: Calcium influx into neurons can solely account for cell contact-dependent neurite outgrowth stimulated by transfected L1. J Cell Biol 1992, 119:883-892.

68. Doherty P, Singh A, Rimon G, Bolsover SR, Walsh FS: Thy-1 antibodytriggered neurite outgrowth requires an influx of calcium into neurons via N- and L-type calcium channels. J Cell Biol 1993, 122:181-189.

69. Ohbayashi K, Fukura H, Inoue HK, Komiya Y, Igarashi M: Stimulation of L-type $\mathrm{Ca} 2+$ channel in growth cones activates two independent signaling pathways. J Neurosci Res 1998, 51:682-696.

70. Kiselyov W, Skladchikova G, Hinsby AM, Jensen PH, Kulahin N, Soroka V, Pedersen N, Tsetlin V, Poulsen FM, Berezin V, Bock E: Structural basis for a direct interaction between FGFR1 and NCAM and evidence for a regulatory role of ATP. Structure 2003, 11:691-701.

71. Kochoyan A, Poulsen FM, Berezin V, Bock E, Kiselyov W: Structural basis for the activation of FGFR by NCAM. Protein Sci 2008, 17:1698-1705.

72. Bojesen KB, Clausen O, Rohde K, Christensen C, Zhang L, Li S, Kohler L, Nielbo S, Nielsen J, Gjorlund MD, et al: Nectin-1 binds and signals through the fibroblast growth factor receptor. J Biol Chem 2012, 287:37420-37433.

73. Williams EJ, Furness J, Walsh FS, Doherty P: Activation of the FGF receptor underlies neurite outgrowth stimulated by L1, N-CAM, and N-cadherin. Neuron 1994, 13:583-594. 
74. Kulahin N, Li S, Hinsby A, Kiselyov V, Berezin V, Bock E: Fibronectin type III (FN3) modules of the neuronal cell adhesion molecule L1 interact directly with the fibroblast growth factor (FGF) receptor. Mol Cell Neurosci 2008, 37:528-536.

75. Williams EJ, Walsh FS, Doherty P: The production of arachidonic acid can account for calcium channel activation in the second messenger pathway underlying neurite outgrowth stimulated by NCAM, N-cadherin, and L1. J Neurochem 1994, 62:1231-1234.

76. $\mathrm{Hu} X \mathrm{Q}$, Singh N, Mukhopadhyay D, Akbarali HI: Modulation of voltagedependent $\mathrm{Ca} 2+$ channels in rabbit colonic smooth muscle cells by c-Src and focal adhesion kinase. J Biol Chem 1998, 273:5337-5342.

77. Bodrikov V, Leshchyns'ka I, Sytnyk V, Overvoorde J, den Hertog J, Schachner M: RPTPalpha is essential for NCAM-mediated p59fyn activation and neurite elongation. J Cell Biol 2005, 168:127-139.

78. Schmid RS, Pruitt WM, Maness PF: A MAP kinase-signaling pathway mediates neurite outgrowth on $\mathrm{L} 1$ and requires Src-dependent endocytosis. J Neurosci 2000, 20:4177-4188.

79. Beggs HE, Soriano P, Maness PF: NCAM-dependent neurite outgrowth is inhibited in neurons from Fyn-minus mice. J Cell Biol 1994, 127:825-833.

80. Beggs HE, Baragona SC, Hemperly JJ, Maness PF: NCAM140 interacts with the focal adhesion kinase p125(fak) and the SRC-related tyrosine kinase p59(fyn). J Biol Chem 1997, 272:8310-8319.

81. Tedford HW, Zamponi GW: Direct G protein modulation of Cav2 calcium channels. Pharmacol Rev 2006, 58:837-862.

82. Strock J, Diverse-Pierluissi MA: Ca2+ channels as integrators of $\mathrm{G}$ proteinmediated signaling in neurons. Mol Pharmacol 2004, 66:1071-1076.

83. Bunney TD, Katan M: PLC regulation: emerging pictures for molecular mechanisms. Trends Biochem Sci 2011, 36:88-96.

84. Kolkova K, Stensman H, Berezin V, Bock E, Larsson C: Distinct roles of PKC isoforms in NCAM-mediated neurite outgrowth. J Neurochem 2005, 92:886-894.

85. Leshchyns'ka I, Sytnyk V, Morrow JS, Schachner M: Neural cell adhesion molecule (NCAM) association with PKCbeta2 via betal spectrin is implicated in NCAM-mediated neurite outgrowth. J Cell Biol 2003, 161:625-639.

86. Bodrikov V, Sytnyk V, Leshchyns'ka I, den Hertog J, Schachner M: NCAM induces CaMKIlalpha-mediated RPTPalpha phosphorylation to enhance its catalytic activity and neurite outgrowth. J Cell Biol 2008, 182:1185-1200.

87. Sytnyk V, Leshchyns'ka I, Nikonenko AG, Schachner M: NCAM promotes assembly and activity-dependent remodeling of the postsynaptic signaling complex. J Cell Biol 2006, 174:1071-1085.

88. Kadmon G, von Bohlen und Halbach F, Horstkorte R, Eckert M, Altevogt P, Schachner M: Evidence for cis interaction and cooperative signalling by the heat-stable antigen nectadrin (murine CD24) and the cell adhesion molecule L1 in neurons. Eur J Neurosci 1995, 7:993-1004.

89. Santuccione A, Sytnyk V, Leshchyns'ka I, Schachner M: Prion protein recruits its neuronal receptor NCAM to lipid rafts to activate p59fyn and to enhance neurite outgrowth. J Cell Biol 2005, 169:341-354

90. Ooashi N, Futatsugi A, Yoshihara F, Mikoshiba K, Kamiguchi H: Cell adhesion molecules regulate $\mathrm{Ca} 2+-$ mediated steering of growth cones via cyclic AMP and ryanodine receptor type 3. J Cell Biol 2005, 170:1159-1167.

91. Utton MA, Eickholt B, Howell FV, Wallis J, Doherty P: Soluble N-cadherin stimulates fibroblast growth factor receptor dependent neurite outgrowth and $\mathrm{N}$-cadherin and the fibroblast growth factor receptor co-cluster in cells. J Neurochem 2001, 76:1421-1430.

92. Sanchez-Heras E, Howell FV, Williams G, Doherty P: The fibroblast growth factor receptor acid box is essential for interactions with $\mathrm{N}$-cadherin and all of the major isoforms of neural cell adhesion molecule. J Biol Chem 2006, 281:35208-35216.

93. Suyama K, Shapiro I, Guttman M, Hazan RB: A signaling pathway leading to metastasis is controlled by $\mathrm{N}$-cadherin and the FGF receptor. Cancer Cell 2002, 2:301-314.

94. Piccoli G, Rutishauser U, Bruses JL: N-cadherin juxtamembrane domain modulates voltage-gated Ca2+ current via RhoA GTPase and Rho-associated kinase. J Neurosci 2004, 24:10918-10923.

95. White MG, Crumling MA, Meriney SD: Developmental changes in calcium current pharmacology and somatostatin inhibition in chick parasympathetic neurons. J Neurosci 1997, 17:6302-6313.

96. Toledo MS, Suzuki E, Handa K, Hakomori S: Effect of ganglioside and tetraspanins in microdomains on interaction of integrins with fibroblast growth factor receptor. J Biol Chem 2005, 280:16227-16234.
97. Carbone E, Carabelli V, Cesetti T, Baldelli P, Hernandez-Guijo JM, Giusta L: Gprotein- and CAMP-dependent L-channel gating modulation: a manyfold system to control calcium entry in neurosecretory cells. Pflugers Arch 2001, 442:801-813.

98. Carlson SS, Valdez G, Sanes JR: Presynaptic calcium channels and alpha3integrins are complexed with synaptic cleft laminins, cytoskeletal elements and active zone components. J Neurochem 2010, 115:654-666.

99. Wu G, Lu ZH, Obukhov AG, Nowycky MC, Ledeen RW: Induction of calcium influx through TRPC5 channels by cross-linking of GM1 ganglioside associated with alpha5beta1 integrin initiates neurite outgrowth. J Neurosci 2007, 27:7447-7458.

100. Gees M, Colsoul B, Nilius B: The role of transient receptor potential cation channels in Ca2+ signaling. Cold Spring Harb Perspect Biol 2010, 2:a003962.

101. Bollimuntha S, Selvaraj S, Singh BB: Emerging roles of canonical TRP channels in neuronal function. Adv Exp Med Biol 2011, 704:573-593.

102. Ramsey IS, Delling M, Clapham DE: An introduction to TRP channels. Annu Rev Physiol 2006, 68:619-647.

103. Chao JT, Gui P, Zamponi GW, Davis GE, Davis MJ: Spatial association of the Cav1.2 calcium channel with alpha5beta1-integrin. Am J Physiol Cell Physiol 2011, 300:C477-C489.

104. Suh HN, Han HJ: Fibronectin-induced VEGF receptor and calcium channel transactivation stimulate GLUT-1 synthesis and trafficking through PPARgamma and TC10 in mouse embryonic stem cells. Stem Cell Res 2013, 10:371-386

105. Jacques-Fricke BT, Seow Y, Gottlieb PA, Sachs F, Gomez TM: Ca2+ influx through mechanosensitive channels inhibits neurite outgrowth in opposition to other influx pathways and release from intracellular stores. J Neurosci 2006, 26:5656-5664.

106. Kerstein PC, Jacques-Fricke BT, Rengifo J, Mogen BJ, Williams JC, Gottlieb PA, Sachs F, Gomez TM: Mechanosensitive TRPC1 channels promote calpain proteolysis of talin to regulate spinal axon outgrowth. J Neurosci 2013, 33:273-285.

107. Togashi K, von Schimmelmann MJ, Nishiyama M, Lim CS, Yoshida N, Yun B, Molday RS, Goshima Y, Hong K: Cyclic GMP-gated CNG channels function in Sema3A-induced growth cone repulsion. Neuron 2008, 58:694-707.

108. Zhao Y, Araki S, Wu J, Teramoto T, Chang YF, Nakano M, Abdelfattah AS, Fujiwara M, Ishihara T, Nagai T, Campbell RE: An expanded palette of genetically encoded $\mathrm{Ca}(2)(+)$ indicators. Science 2011, 333:1888-1891.

109. Shigetomi E, Kracun S, Khakh BS: Monitoring astrocyte calcium microdomains with improved membrane targeted GCaMP reporters. Neuron Glia Biol 2010, 6:183-191.

110. Chen TW, Wardill TJ, Sun Y, Pulver SR, Renninger SL, Baohan A, Schreiter ER, Kerr RA, Orger MB, Jayaraman $V$, et al: Ultrasensitive fluorescent proteins for imaging neuronal activity. Nature 2013, 499:295-300.

111. Akerboom J, Chen TW, Wardill TJ, Tian L, Marvin JS, Mutlu S, Calderon NC, Esposti F, Borghuis BG, Sun XR, et al: Optimization of a GCaMP calcium indicator for neural activity imaging. J Neurosci 2012, 32:13819-13840.

\section{doi:10.1186/1478-811X-11-94}

Cite this article as: Sheng et al:: Cell adhesion and intracellular calcium signaling in neurons. Cell Communication and Signaling 2013 11:94.

\section{Submit your next manuscript to BioMed Central and take full advantage of:}

- Convenient online submission

- Thorough peer review

- No space constraints or color figure charges

- Immediate publication on acceptance

- Inclusion in PubMed, CAS, Scopus and Google Scholar

- Research which is freely available for redistribution 